\title{
Growth of Street Trees in Copenhagen With Emphasis on the Effect of Different Establishment Concepts
}

\author{
Oliver Bühler, Palle Kristoffersen, and Søren Ugilt Larsen
}

\begin{abstract}
Limited rooting space is considered a major problem for growth of street trees. Different approaches to extend the soil volume accessible to roots have been implemented in Copenhagen, Denmark, during the last 15 years. The presented survey investigates growth and vitality of trees planted in 1) structural, load-bearing soil; 2) sand-based loadbearing soil; and 3) so-called super planting pits and trees planted in conventional planting pits. The trees were either street trees or situated on paved squares. The results provide evidence that vitality of recently established street trees in Copenhagen generally is on an acceptable level. Furthermore, tree growth in both of the load-bearing materials allowing for root growth was found to be comparable to tree growth in conventional planting pits, and those methods are therefore considered applicable at sites where conventional pits cannot be established. However, tree growth in super planting pits was superior to any of the other methods both in regard to growth rates and vitality. This method is therefore recommended wherever space for large planting pits with open surfaces can be made available. Growth of trees planted in conventional pits varied considerably, reflecting the broad range of different conditions the term "conventional planting" pit covers.

Key Words. Acer; load-bearing soils; planting pit design; Platanus; Populus; road foundations; rooting volume; sand mix; stem increment; stone matrix; structural soils; Tilia; tree growth; urban trees.
\end{abstract}

The majority of street trees are exposed to a challenging environment for tree growth. As a result, growth, vitality, and ultimately the lifespan of street trees may be reduced considerably compared with trees growing in their natural habitats. Gilbertson and Bradshaw (1990), for example, reported that $23 \%$ of newly planted trees in Liverpool had died after three growing seasons, and estimates on the average lifespan of urban trees are far lower than what would be expected on more favorable, natural sites (Balder et al. 1997). The reasons for this are complex, but limited soil volumes and increased soil compaction are some of the major explanations for the poor performance of many urban trees.

Although the planting pit of a tree may be connected to surrounding soil volumes within reach for the tree roots, these soil volumes are mostly load-bearing layers for pavements or buildings and, consequently, highly compacted.

One of the parameters that indicate whether a soil is compacted is soil bulk density. Soil bulk density is, to some degree and in combination with other soil characteristics, reflective of the mechanical resistance roots meet in the soil. Root growth of Quercus robur was impeded when soil bulk density exceeded $1.5 \mathrm{~g} / \mathrm{cm}^{3}$ (Grabosky and Bassuk 1996), and Malus domestica seedlings also exhibited reduced shoot length, leaf area, leaf size, and dry weight of leaves, shoots, and roots when grown in soils compacted to bulk densities of $1.5 \mathrm{~g} / \mathrm{cm}^{3}$ (Ferree et al. 2004). Mullins (1991) states that for many soil types, root growth is limited seriously when bulk densities exceed $1.6 \mathrm{~g} / \mathrm{cm}^{3}$. Road foundations in Denmark are typically compacted to bulk densities exceeding $2 \mathrm{~g} / \mathrm{cm}^{3}$ (Kristoffersen 1999).

Although the compaction of base materials is intended and a prerequisite for the performance of load-bearing materials, compaction may also occur unintended in the course of construction works. An investigation by Randrup (1997) reveals soil bulk densities on construction sites in Denmark averaging at $1.94 \mathrm{~g} / \mathrm{cm}^{3}$.

Because of the high level of compaction of the loadbearing layers of many urban structures, the root zone of street trees is often confined to the rather limited soil volume of the planting pit (Kristoffersen 1999).

In an effort to extend rooting volumes and thus enhance the success rates of urban tree plantations, the city of Copenhagen has from the beginning of the 1990s implemented different establishment methods: 1) conventional establishment, 2) structural soils, 3) sand-mix, and 4) super planting pits. These establishment methods are described in detail.

\section{Conventional Establishment of Trees in Copenhagen}

Typically, trees are established in planting pits of varying sizes dependant on site possibilities and limitations. Surface area varies between 1.5 and $6 \mathrm{~m}^{2}\left(16.2\right.$ and $\left.64.8 \mathrm{ft}^{2}\right)$, aver- 
aging $3.2 \mathrm{~m}^{2}\left(34.6 \mathrm{ft}^{2}\right)$ (Table 1). Topsoil is exchanged with a sand-based tree growth substrate to a depth of $\approx 50$ to $60 \mathrm{~cm}$ ( $\approx 20$ to 24 in). The original soil beneath that layer is loosened, and installations to improve drainage may be installed. In this survey, conventional establishment, however, also covers establishment in planting stripes covered with turf or gravel, i.e., any situation where none of the three alternative approaches (structural soils, sand mixes, or super planting pits) have been applied.

\section{Structural Soils}

This method of extending the rooting zone to soil volumes under sealed surfaces was first described and tested by Grabosky and Bassuk (1995). Structural soil is basically a mixture of gravel and soil and should meet two requirements; the gravel fraction should provide a skeletal structure that transfers loads from paved surfaces to the subsoil, and the soil fraction in the voids between the stones should provide the possibility of root growth. In addition to opening up soil volumes under paved surfaces for root growth, structural soils were also thought to reduce sidewalk damages caused by shallow root systems as described by, for example, Kopinga (1994) and Nicoll and Armstrong (1998), because they would enable roots to explore deeper soil layers.

Container growth tests by Grabosky and Bassuk (1996) and Kristoffersen (1999) revealed that roots actually would grow into structural soils. Kristoffersen (1999) established that structural soils resulted in total tree growth rates comparable to the sole use of topsoil as growth media. However, root/shoot ratios increased when structural soils were used, indicating that less shoot growth will be obtained in a given volume of structural soils compared with a similar volume of uncompacted pure topsoil. This altered root/shoot ratio of trees established in structural soils was also observed in a container experiment with Ficus benjamina by Loh et al. (2003), who, however, also reported lower leaf tissue N content and reduced growth of plants grown in structural soils compared with plants grown in topsoil only.

Smiley et al. (2006) investigated several growth and vitality parameters of trees grown in structural soils and report

Table 1. Properties of the different establishment concepts.

\begin{tabular}{llcl}
\hline $\begin{array}{l}\text { Establishment } \\
\text { method }\end{array}$ & $\begin{array}{l}\text { Depth of } \\
\text { excavation }[\mathrm{m}]^{\mathrm{y}}\end{array}$ & $\begin{array}{l}\text { Mean surface } \\
\text { area }\left[\mathrm{m}^{2}\right]^{\mathrm{x}}\end{array}$ & $\begin{array}{l}\text { Load bearing } \\
\text { (light traffic) }\end{array}$ \\
\hline Conventional & 0.60 & 3.2 & No \\
Structural soil & 0.60 & 1.6 & Yes \\
Sand mix & 0.60 & 1.7 & Yes \\
Super planting pit & $0.80^{\mathrm{z}}$ & 12 & No \\
\hline
\end{tabular}

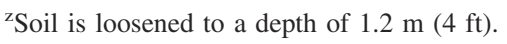

${ }^{\mathrm{y}}$ According to principal dimensional sketch.

${ }^{\mathrm{x}}$ Mean area of the unsealed surface of the pits in this survey. significant growth reductions of trees grown in structural soil compared with trees grown in uncompacted soil covered with suspended paving.

Lemaire and Sorin (1997) report experiences from Angers, France, with structural soils composed of $35 \%(\mathrm{v} / \mathrm{v})$ organic soil and $65 \%(\mathrm{v} / \mathrm{v})$ stones (40/90). All plantations established using this "mélange terre-pierre" were reported to result in satisfactory development, and root growth into the stone-soil mixture was observed.

\section{Sand-Based Soils}

Initially described as Amsterdam tree soil by Couenberg (1994), sand-based soils are supposed to function as growth media and support paving for light traffic. They are composed of a sand fraction consisting of medium coarse sand with uniform particle sizes mixed with soil rich in decomposed, organic matter ( $4 \%$ to $5 \% \mathrm{w} / \mathrm{w})$ and clay ( $2 \%$ to $4 \% \mathrm{w} / \mathrm{w})$.

This substrate is then filled into the planting pits and/or adjacent paved areas where root growth is desired. According to Couenberg (1994), the substrate should be filled into the pit and compacted to $\approx 70 \%$ to $80 \%$ proctor density in two layers of $\approx 40$ to $50 \mathrm{~cm}$ ( $\approx 16$ to $20 \mathrm{in})$.

In contrast to encouraging results by Couenberg (1994), Kristoffersen (1999) reveals possible risks of this establishment method, because a sand mix containing $2.2 \%$ organic matter, compacted to $80 \%$ standard proctor (corresponding to $1.4 \mathrm{~g} / \mathrm{m}^{3}$ ), had a tendency to waterlog and thus obstructed root growth. This indicates a need for more detailed specification of composition and installation of this material, in particular in regard to compaction.

\section{Super Planting Pits}

The design of super planting pits does not involve loadbearing layers accessible to root growth below paved surfaces. Instead, a super planting pit offers a large, unsealed surface $\left(>12 \mathrm{~m}^{2} ; 129.6 \mathrm{ft}^{2}\right)$ in combination with deep soil loosening, providing at least $15 \mathrm{~m}^{3}\left(525 \mathrm{ft}^{3}\right)$ of soil for each tree. A typical super planting pit profile can be described as exchanged topsoil from 0 to $60 \mathrm{~cm}$ ( 0 to 24 in), exchanged mineral base soil from 60 to $80 \mathrm{~cm}$ (24 to $32 \mathrm{in}$ ), and loosened original soil from 80 to $120 \mathrm{~cm}$ (32 to $48 \mathrm{in}$ ).

\section{Aims of the Survey}

Experiences with the alternative establishment methods generally only cover relatively young plantations or experimental setups. Information on the actual in situ performance of materials designed to perform equally well as load-bearing layer and as root zone for urban trees is still sparse.

Expenses for establishment of trees with any of the three alternative methods exceed the costs of conventional tree establishment, and information about growth and vitality of 
urban trees is therefore considered a valuable tool for tree managers to create functioning plantings at reasonable costs.

\section{MATERIAL AND METHODS Selection of Street Tree Plantations}

To counterbalance the variation expected to be met under urban conditions, the survey was designed to include a high number of sites and trees. Plantations were selected based on information from the Copenhagen tree inventory. The following selection criteria had to be met by each plantation included in the survey:

1. Time of establishment between 1990 and Spring 2001, thus guaranteeing at least five growth seasons after establishment;

2. Each plantation should consist of a minimum of 10 trees;

3. Information regarding tree size at establishment and planting method used had to be available from the tree inventory; and

4. Cultivars of the following species were included in the survey: Acer (A. platanoides and A. pseudoplatanus), Fraxinus excelsior, Platanus $\times$ acerifolia, Populus candensis, Quercus (Q. palustris, Q. petraea, Q. robur, and Q. rubra), Robinia pseudoacacia, Sorbus (S. aria, S. intermedia, and S. latifolia), Tilia (T. cordata, T. europaea, and T. platyphyllos), Prunus avium and Crataegus lavallei.

As a result of these criteria, the final data set contained information on 2164 trees.

\section{Measurements}

For each tree, stem circumference was measured at a height of $1 \mathrm{~m}$. In addition, a vitality score was assessed on a scale from 0 to 5 (Table 2).

To assess growth rates, information on tree size at time of establishment was obtained in cooperation with the munici-

Table 2. Vitality scores assigned to the street trees.

\begin{tabular}{ll}
\hline Score & Description \\
\hline 0 & Tree dead or dying \\
1 & $\begin{array}{l}\text { Tree growth seriously affected, dead branches, discolored } \\
\text { foliage, sparse crown }\end{array}$ \\
2 & $\begin{array}{l}\text { Tree growth visibly affected, no shoot growth, discolored } \\
\text { foliage }\end{array}$ \\
3 & Tree appears healthy but stagnating, little or no shoot \\
& $\begin{array}{l}\text { growth, crown appears largely dense and without } \\
\text { discolored foliage }\end{array}$ \\
& $\begin{array}{l}\text { Tree appears healthy and in growth, annual shoot growth } \\
\text { less than } 30 \text { cm (12 in) }\end{array}$ \\
& $\begin{array}{l}\text { Tree appears healthy and growing vigorously, annual } \\
\text { shoot growth exceeding } 30 \text { cm (12 in), high crown } \\
\text { density and no signs of discolored foliage }\end{array}$ \\
&
\end{tabular}

palities of Copenhagen (Vej \& Park). Because available information only denoted size intervals [e.g., stem circumference of 18 to $20 \mathrm{~cm}$ ( 7.2 to $8 \mathrm{in}), 20$ to $25 \mathrm{~cm}$ ( 8 to $10 \mathrm{in}$ ) instead of accurate sizes), size was assumed to correspond to the average of the range minima and maxima, i.e., trees planted with a stem circumference of 18 to $20 \mathrm{~cm}$ ( 7.2 to 8 in) were assumed to have an average stem circumference of 19 $\mathrm{cm}$ (7.6 in).

As a reference, stem increment of most species and cultivars represented in the evaluation was measured at the Urban Tree Arboretum in Hørsholm, Denmark. Here, many urban tree species are represented established with six replicates in 2001 on a formerly afforested area.

\section{Statistics and Data Analysis}

Annual increment rates were calculated for each tree as differences between stem diameter at the time of establishment and measured stem diameter in 2005 divided by number of growing seasons.

Analysis of variance (ANOVA) using the GLM procedure in SAS, version 8.02 (SAS Institute, Cary, NC) was used to compare yearly stem diameter increment means of street trees in response to the different establishment methods. ANOVA was first performed on the whole data set with stem diameter increment and vitality score as response variables and establishment method and genus as explanatory variables. Because significant interactions between genus and establishment method were determined in regard to stem increment, ANOVA was subsequently performed on data sets consisting of only Platanus, Tilia, and Acer, respectively, i.e., genera whose data set contained plantings with different establishment methods. In regard to vitality, no significant interactions were determined and the reported results originate from the initial ANOVA.

When ANOVA results were significant $(P<0.05)$, differences between means were determined by Tukey's studentized range tests for $P<0.05$.

\section{Stem Growth}

The overall mean stem diameter increment of all 2164 trees was $0.96 \mathrm{~cm}$ (0.38 in). With $1.99 \mathrm{~cm}$ (0.80 in), Populus had by far the highest mean annual stem diameter increment. Prunus $(1.35 \mathrm{~cm} ; 0.54 \mathrm{in})$, Platanus $(1.01 \mathrm{~cm} ; 0.4 \mathrm{in})$, and Fraxinus $(0.98 \mathrm{~cm} ; 0.39$ in) had high increment rates, too, also compared with growth rates of the same genera at the urban tree arboretum. Platanus, Fraxinus, and Prunus achieve at least $80 \%$ of the growth at the arboretum (Table 3 ).

The distribution of observation pr. genus reveals a high number of Tilia (632), Platanus (690), and Acer (256) street trees. Of all genera in this investigation, these three genera were established with different methods. 
Table 3. Mean vitality score and annual increment rates of street tree genera in Copenhagen, Denmark, establishment methods not considered; and increment rates of the corresponding genera at the urban tree arboretum in good soil conditions.

\begin{tabular}{|c|c|c|c|c|c|c|}
\hline \multirow[b]{2}{*}{ Genus } & \multirow[b]{2}{*}{$\mathrm{N}$} & \multirow{2}{*}{$\begin{array}{l}\text { Vitality } \\
\text { Mean }\end{array}$} & \multicolumn{2}{|c|}{$\begin{array}{c}\text { Annual diameter increment, } \\
\text { street trees }(\mathrm{cm})\end{array}$} & \multirow{2}{*}{$\begin{array}{l}\text { Annual diameter increment } \\
\text { arboretum trees }(\mathrm{cm})\end{array}$} & \multirow{2}{*}{$\begin{array}{l}\text { Increment of street trees } \\
\text { in relation to arboretum } \\
\text { trees }(\%)\end{array}$} \\
\hline & & & Mean & Std & & \\
\hline Acer & 256 & 4.3 & 0.69 & 0.25 & 1.27 & 54 \\
\hline Crataegus & 28 & 3.2 & 0.59 & 0.21 & & \\
\hline Fraxinus & 93 & 4.3 & 0.98 & 0.28 & 1.22 & 80 \\
\hline Platanus & 690 & 4.3 & 1.01 & 0.43 & 1.09 & 93 \\
\hline Populus & 81 & 4.9 & 1.99 & 0.40 & & \\
\hline Prunus & 135 & 4.6 & 1.35 & 0.38 & 1.49 & 91 \\
\hline Quercus & 78 & 3.4 & 0.69 & 0.23 & 1.01 & 68 \\
\hline Robinia & 43 & 4.7 & 1.15 & 0.30 & 1.57 & 73 \\
\hline Sorbus & 128 & 4.3 & 0.80 & 0.27 & & \\
\hline Tilia & 632 & 4.2 & 0.85 & 0.35 & 1.42 & 60 \\
\hline All & 2164 & 4.3 & 0.96 & 0.44 & 1.29 & 74 \\
\hline
\end{tabular}

A direct comparison of the four establishment methods comprising all genera reveals that stem diameter increment rates are very similar for conventional planting method $(0.95$ $\mathrm{cm} ; 0.38 \mathrm{in})$, establishment in structural soil $(0.95 \mathrm{~cm} ; 0.38$ in), and establishment in sand mix $(0.94 \mathrm{~cm} ; 0.38$ in). Trees established in super planting pits had significantly higher growth rates $(1.11 \mathrm{~cm} ; 0.44 \mathrm{in})$. However, because the ANOVA also determined significant interactions between establishment method and tree genus, growth response to the different establishment methods is in the following illustrated for those genera that actually are established using different methods (Tilia, Platanus, and Acer), too.

Mean yearly stem increment of all Tilia spp. street trees in this survey was $0.85 \mathrm{~cm}$ (0.34 in). This corresponds to $60 \%$ of stem growth rates determined at the urban tree arboretum (Table 3).

Stem increment rates for the genus Tilia were significantly higher when established in super planting pits $(1.1 \mathrm{~cm}$; 0.44 in) compared with the other establishment methods. Conventional establishment and establishment in structural soil and sand mix did not result in significant differences (Table 4).
Mean yearly stem increment of all Platanus in this survey was $1.01 \mathrm{~cm}(0.40 \mathrm{in})$ corresponding to $93 \%$ of stem growth at the urban tree arboretum (Table 3). Platanus achieved significantly better growth results after establishment in sand mix compared with all other establishment methods. However, also, establishment in conventional pits and super planting pits resulted in diameter increments above $1 \mathrm{~cm} /$ year $(0.4$ in/year). In structural soils, stem increment was significantly lower compared with all other methods (Table 4).

Mean yearly stem diameter increment for all Acer street trees in this survey was $0.69 \mathrm{~cm}(0.28 \mathrm{in})$ corresponding to $54 \%$ of stem increment at the urban tree arboretum (Table 3).

Street tree plantations comprising Acer platanoides and $A$. pseudoplatanus had significantly higher increment rates when established conventionally (Table 4).

Two plantations offered the opportunity to investigate growth responses for the same cultivar established at the same site but with different methods. A plantation of Tilia platyphyllos 'Örebro', established partly in structural soils with an unsealed surface of $1 \mathrm{~m}^{2}\left(10.8 \mathrm{ft}^{2}\right)$ and partly in a conventional pit with a unsealed surface of $\approx 5.5 \mathrm{~m}^{2}(\approx 59.4$ $\mathrm{ft}^{2}$ ), revealed significant higher increment rates of the trees

Table 4. Annual stem diameter increment in response to establishment method for Acer, Platanus, and Tilia in Copenhagen, Denmark. ${ }^{2}$

\begin{tabular}{|c|c|c|c|c|c|c|c|c|c|}
\hline \multirow[b]{3}{*}{ Establishment method } & \multicolumn{9}{|c|}{ Annual diameter increment $(\mathrm{cm})$} \\
\hline & \multicolumn{3}{|c|}{ Acer } & \multicolumn{3}{|c|}{ Platanus } & \multicolumn{3}{|c|}{ Tilia } \\
\hline & $\mathrm{N}$ & Mean & Std & $\mathrm{N}$ & Mean & Std & $\mathrm{N}$ & Mean & Std \\
\hline Structural soil & 29 & $0.49 \mathrm{~b}$ & 0.18 & 174 & $0.87 \mathrm{c}$ & 0.3 & 149 & $0.88 \mathrm{~b}$ & 0.23 \\
\hline Sand mix & 18 & $0.31 \mathrm{c}$ & 0.09 & 17 & $1.84 \mathrm{a}$ & 0.18 & 59 & $0.88 \mathrm{~b}$ & 0.39 \\
\hline Super planting pit & & & & 48 & $1.03 \mathrm{bc}$ & 0.18 & 25 & $1.27 \mathrm{a}$ & 0.22 \\
\hline
\end{tabular}

${ }^{\mathrm{z}}$ Mean values in the same column differ significantly when followed by different letters (Tukey test, $P<0.05$ ). 
planted conventionally [ $1.53 \mathrm{~cm}$ ( $0.61 \mathrm{in}), n=14]$ compared with trees established in structural soil $[0.86 \mathrm{~cm}(0.34 \mathrm{in})$, $n=26]$. A plantation of Tilia europaea 'Pallida' established partly in super planting pits [1.38 $\mathrm{cm}$ (0.55 in), $n=16]$ and partly in structural soil [0.89 $\mathrm{cm}(0.36 \mathrm{in}), n=4]$ showed the same tendency, however, without being statistically significant.

Growth differences of species belonging to the same genus were small and insignificant for Quercus, Acer, and Tilia, except for Tilia platyphyllos, which achieved a mean stem increment $1.08 \mathrm{~cm}$ (0.43 in), significantly higher than $T$. europaea $(0.85 \mathrm{~cm} ; 0.34 \mathrm{in})$ and $T$. cordata $(0.81 \mathrm{~cm} ; 0.32 \mathrm{in})$. Significant differences of mean stem increment was also determined between all species of Sorbus with $S$. latifolia achieving $1.02 \mathrm{~cm}$ (0.41 in), S. intermedia $0.77 \mathrm{~cm}(0.31 \mathrm{in})$, and $S$. aria $0.64 \mathrm{~cm}$ (0.26 in). Fraxinus, Platanus, Populus, Robinia, Prunus, and Crataegus are only represented by one species each.

\section{Vitality}

With 1733 of the 2164 trees in this survey achieving vitality score 4 or $5,80 \%$ of all trees are within the vitality range describing functioning street trees. Only Quercus and Crataegus had mean vitality scores ranging below 3.5. Mean vitality scores above 4.5 were obtained by Populus, Prunus, and Robinia (Table 3).

Vitality of trees established in super planting pits differed significantly from trees established in structural soil, sand mix, and conventional planting pits (Table 5).

\section{DISCUSSION}

Comparing the different establishment methods over the whole range of observations, neither significant nor relevant differences were determined when comparing stem growth in response to conventional establishment, establishment in structural soils, and establishment in sand mixes, respectively. It is thus evident that establishment of trees in base materials allowing root growth is possible and allows for acceptable tree development at least for the first 15 years after establishment. However, super planting pits providing a large open surface area and large soil volume result in significantly higher stem growth and vitality score.

Table 5. Mean vitality score of all 2164 trees in response to establishment method. ${ }^{z}$

\begin{tabular}{lrll}
\hline & $\mathrm{N}$ & Mean vitality score & Std \\
\hline Conventional & 1461 & $4.3 \mathrm{a}$ & 0.03 \\
Sand mix & 94 & $4.2 \mathrm{a}$ & 0.13 \\
Structural soil & 536 & $4.1 \mathrm{a}$ & 0.05 \\
Super planting pit & 73 & $4.9 \mathrm{~b}$ & 0.03 \\
\hline
\end{tabular}

${ }^{\mathrm{z}}$ Mean values in the same column differ significantly when followed by different letters (Tukey test, $P<0.05$ ).
Populus, Platanus, and Fraxinus achieved good growth results in this survey and may thus be regarded as good street tree candidates. Populus in particular may be regarded as a promising option for locations, where expensive approaches are impractical, because it achieves good growth rates even at utterly unprepared sites. On the other hand, possible damage to paved surfaces as well as pipelines by the vigorously growing root system has to be taken into consideration when establishing poplars (see e.g., Kopinga 1994; Gilman 2006).

Platanus achieved particularly good results in sand mix and is the only species in this survey that actually achieves better results in sand mix compared with the other establishment methods. Although this is only documented for 17 trees in one single plantation, the combination of plane trees and sand mix appears promising. Growth rates in super planting pits are comparable to growth rates of trees established conventionally, suggesting that plane trees thrive even when established under less favorable conditions and that super planting pits may be reserved for other, more demanding species.

Tilia clearly grows best in super planting pits. A comparison with growth of Tilia at the urban tree arboretum also indicates that growth conditions for Tilia in the urban environment leave room for improvement. Based on this survey, super planting pits are a potent option to enhance the performance of Tilia street trees.

A closer look on the growth of Acer reveals that this genus achieves high growth rates only if planted in conventional systems. However, this result may be colored by the fact that the one site representing Norway maple in sand mixes is situated at an especially heavily trafficked bus terminal and experienced problems during establishment. Nevertheless, based on the presented data, the tree manager should not rely on designed soils to establish A. platanoides and A. pseudoplatanus on difficult sites but instead use this genera on locations offering naturally good conditions, as, for example, connected planting strips with permeable surface situated at some distance to the road to avoid deposition of deicing salt (Pedersen et al. 2000).

Because establishment of trees in these alternative road base materials is more expensive than conventional establishment, their adoption should be preceded by careful consideration of alternatives. Their cardinal use should be restricted to sites that are unsuitable for conventional establishment, but where tree establishment is absolutely desired. Wherever the urban structures allow for it, super planting pits and comparable methods offering large open surface areas and large soil volumes will provide superior growth conditions for street trees, as shown in other studies, too (Grabosky and Gilman 2004; Smiley et al. 2006).

When comparing the different establishment methods in regard to data variation (e.g., standard deviation in Table 4), it becomes obvious that the super planting pits result in a 
more uniform growth than the other establishment methods. Especially the conventional and the sand mix methods appear to cover a fairly large variation. Concerning the sand mixes, some of the problems encountered may be caused by drainage difficulties as experienced by Kristoffersen (1999) or by a soil compaction level too high for root growth. However, that sand mixes are indeed an alternative to structural soils is indicated by a vigorously growing planting of Platanus established in sand mix [mean annual stem diameter increment of $1.84 \mathrm{~cm}(0.72 \mathrm{in})]$.

Interpreting the results of this survey, it should be taken into account that even when establishing a tree using structural soil or sand mix, the actual planting pit will often be filled with normal tree planting substrate also used for conventional plantings. Thus, in the first years after establishment, this soil volume will constitute the main source of water and nutrients for the tree. With the roots growing out of the actual planting pit, root processes will move into the structural soils, which will then gain in importance. Differences between growth reactions in response to the investigated establishment methods are therefore supposed to develop with the course of time and continuing tree (root) growth.

In addition to a mere extension of the rooting zone, amelioration of the soil composition or soil amendments may be considered as possibilities to optimize root growth conditions and/or direct root growth into desired soil volumes (Braun and Fluckiger 1998; Ferrini et al. 2005).

Although tree growth generally is considered acceptable for all establishment methods, differences appear when trees are planted with different methods on the same site. Therefore, if the ambition is to achieve a uniform plantation, the same establishment method should be applied to all trees.

Experiences from France indicate that roots indeed are actively growing into the structural soils applied (Lemaire and Sorin 1997), and Dutch experiences report similar findings for sand mixes (Couenberg 1994). However, quantifications of root growth in load-bearing materials on actual street sites are currently not available, and as surfaces above those types of materials typically are paved, root growth studies are somewhat complicated. Although it is now established that the aboveground parts of trees established in root-friendly base materials actually grow, evidence of roots actually growing out of the planting pit and into the base materials is still sparse, and further research on root development in loadbearing soils is required.

Because this survey was carried out on real street tree plantations in the city of Copenhagen, many potentially unknown influences on tree growth performance entailed a high variation of the obtained data. This variation was to be expected and counterbalanced by a large data set. Although statistically a challenge, a study of street tree growth in a real urban context is considered to reveal valuable information.
A certain degree of uncertainty concerning the estimation of tree size at the time of establishment may have affected the growth calculations. Because the majority of the trees incorporated in the survey were planted as 18 to $20 \mathrm{~cm}$ ( 7.2 to $8 \mathrm{in}$ ) stem circumference, the risk of false estimates was reduced.

All included genera of street trees achieved less growth on the actual street site compared with the urban tree arboretum. However, site conditions on the arboretum must be considered to be superior to urban sites. Therefore, based on the presented data, growth and vitality of most street tree species established in Copenhagen during the last 5 to 15 years may be characterized as acceptable or even good. Contrasting former studies as, for example, by Gilbertson and Bradshaw (1990), stating a generally poor street tree establishment praxis, this finding accentuates that deliberate planning and establishment procedures result in functioning street tree plantations.

Because many of the trees involved have not yet reached their desired size, and because they eventually will reach limits set by the available soil volume and other constraints, further studies will need to establish potential maximum sizes and life expectancies of street trees planted in accordance to the different establishment concepts. In theory, super planting pits providing the largest soil volumes in combination with a large surface area should supply both more water and nutrition than the other concepts.

\section{CONCLUSIONS}

As a general conclusion based on the presented data, growth and vitality of most of the street trees in Copenhagen planted during the last 5 to 10 years appears to be good.

The alternative tree establishment methods have proven to result in at least comparable tree growth as the conventional establishment method without rooting space enhancements. The super planting pits have proven to be superior to the other planting methods. On the basis of this survey, the use of root-friendly base materials can therefore be recommended for sites where tree establishment is wished for but considered difficult or impossible in a conventional planting pit.

However, as the example of the super planting pits illustrates, extra rooting space in depth combined with a large open surface area results in high growth rates and high uniformity of the plantation. Of the four planting methods, the super planting pits are considered the safest way of establishing trees in the urban environments. Thus, wherever space is available, this method is recommended.

In regard to more specific reactions to the different establishment methods, it was determined that Platanus had extraordinary high growth rates in sand-based mixtures but did not react with higher growth rates to establishment in super planting pits. Tilia had significantly higher growth rates in super planting pits. Acer expressed difficulties when established in root-friendly base materials and thrived best when 
planted in planting stripes with large open surface area. Populus had high growth rates even when planted rather extensively, i.e., without further soil amelioration, and can be used as fast-growing and inexpensive trees on difficult sites or to create temporary green structures when resources are limited and the risk of damage to urban infrastructure is low.

Acknowledgments. This study was conducted on behalf of the City of Copenhagen, Vej \& Park, financed in equal shares by the City of Copenhagen, Vej \& Park, and the Danish Centre for Forest, Landscape and Planning-KVL. We thank Jens Jacob Elkjær Knusen, Klaus Hansen Petersen, and colleagues from Vej \& Park Copenhagen for providing equipment and assistance and for their perpetual interest, inspiration, and help.

\section{LITERATURE CITED}

Balder, H., K. Ehlebracht, and E. Mahler. 1997. Strassenbäume-Planen, Pflanzen, Pflegen am Beispiel Berlin. Berlin, Patzer Verlag. 240 pp.

Braun, S., and W. Fluckiger. 1998. Soil amendments for plantings of urban trees. Soil and Tillage Research 49: 201-209.

Couenberg, E.A.M. 1994. Amsterdam tree soil, pp. 24-33. In The Landscape Below Ground. Watson, G.W., and Neely, D., Eds. Savoy, International Society of Arboriculture.

Ferree, D.C., J.G. Streeter, and Y. Yuncong. 2004. Response of container-grown apple trees to soil compaction. HortScience 39:40-48.

Ferrini, F., A. Giuntoli, F.P. Nicese, S. Pellegrini, and N. Vignozzi. 2005. Effect of fertilization and backfill amendments on soil characteristics, growth, and leaf gas exchange of English oak (Quercus robur L.). Journal of Arboriculture 31:182-190.

Gilbertson, P., and A.D. Bradshaw. 1990. The survival of newly planted trees in inner cities. Arboricultural Journal 14:287-309.

Gilman, E.F. 2006. Deflecting roots near sidewalks. Arboriculture and Urban Forestry 32:18-23.

Grabosky, J., and N. Bassuk. 1995. A new urban tree soil to safely increase rooting volumes under sidewalks. Journal of Arboriculture 21:187-201.

1996. Testing of structural urban tree soil materials for use under pavement to increase street tree rooting volumes. Journal of Arboriculture 22:255-263.

Grabosky, J., and E. Gilman. 2004. Measurement and prediction of tree growth reduction from tree planting space design in established parking lots. Journal of Arboriculture 30:154-159.

Kopinga, J. 1994. Aspects of damage to asphalt road pavings caused by tree roots, pp. 157-164. In The Landscape Below Ground. Watson, G.W., and Neely, D., Eds. Savoy, International Society of Arboriculture.

Kristoffersen, P. 1999. Growing trees in road foundation materials. Arboricultural Journal 23:57-76.
Lemaire, F., and X. Sorin. 1997. Artificialisation du milieu de culture dans les espaces verts urbains, pp. 247-256. In La plante dans la ville. Riviere, L.M., Ed. INRA Editions, les colloques 84 .

Loh, F.C.W., J.C. Grabosky, and N.L. Bassuk. 2003. Growth response of Ficus benjamina to limited soil volume and soil dilution in a skeletal soil container study. Urban Forestry and Urban Greening 2:53-62.

Mullins, C.E. 1991. Physical properties of soils in the urban areas, pp. 87-118. In Soils in the Urban Environment. Bullock, P., and Gregory, P.J., Eds. Oxford, Blackwell Scientific Publications.

Nicoll, B.C., and A. Armstrong. 1998. Development of Prunus root systems in a city street: Pavement damage and root architecture. Arboricultural Journal 22:259-270.

Pedersen, L.B., T.B. Randrup, and M. Ingerslev. 2000. Effects of road distance and protective measures on deicing $\mathrm{NaCl}$ deposition and soil solution chemistry in planted median strips. Journal of Arboriculture 26:238-245.

Randrup, T.B. 1997. Soil compaction on construction sites. Journal of Arboriculture 23:207-210.

Smiley, E.T., L. Calfee, B.R. Fraedrich, and E.J. Smiley. 2006. Comparison of structural and noncompacted soils for trees surrounded by pavement. Arboriculture \& Urban Forestry 32:164-169.

Oliver Bühler (corresponding author)

PhD student

Division of Parks and Urban Landscapes

Danish Centre for Forest, Landscape and Planning

Faculty of Life Sciences

University of Copenhagen

Rolighedsvej 23

DK-1958 Frederiksberg, Denmark

olb@life.ku.dk

Palle Kristoffersen

Senior Advisor, PhD

Division of Parks and Urban Landscapes

Danish Centre for Forest, Landscape and Planning

Faculty of Life Sciences

University of Copenhagen

Rolighedsvej 23

DK-1958 Frederiksberg, Denmark

Søren Ugilt Larsen

Special Advisor, PhD

Danish Agricultural Advisory Service

National Centre

Crop Production

Udkaersvej 15

DK-8200 Aarhus N, Denmark 
Résumé. La limitation de l'espace pour le développement racinaire est considérée comme un problème majeur pour la croissance des arbres de rues. Différentes approches pour augmenter le volume de sol accessible aux racines ont été mises en place dans la ville de Copenhague au Danemark durant les 15 dernières années. Le présent inventaire analyse la croissance et la vitalité des arbres plantés dans a) un sol structurant de fondation, b) un sol sableux de fondation, et c) une super-fosse de plantation ainsi qu'une fosse conventionnelle. Les arbres ont été soient des arbres de rues ou encore des arbres situés dans des carrés pavés. Les résultats ont fourni des preuves à l'effet que la vitalité des arbres de rues récemment établis à Copenhague était généralement à un niveau acceptable. De plus, les arbres qui poussaient dans les deux types de sol de fondation permettant une croissance des racines étaient comparables à ceux qui poussaient dans des fosses conventionnelles; ces méthodes sont de ce fait considérées comme étant applicables sur des sites où les fosses conventionnelles ne peuvent être employées. Quoiqu'il en soit, les arbres dans les super-fosses de plantation étaient supérieurs à ceux de toutes les autres méthodes, et ce en regard des taux de croissance et de vitalité. Cette méthode est de ce fait celle qui est recommandée partout où l'espace pour de grandes fosses de plantation avec des surfaces ouvertes le permet. Le taux de croissance des arbres plantés dans des fosses conventionnelles variait considérablement, ce qui reflétait la vaste gamme de conditions différentes que l'expression fosse de «plantation conventionnelle » couvrait.

Zusammenfassung. Der begrenzte Wurzelraum ist ein großes Problem für das Wachstum von Straßenbäumen. In den letzten 15 Jahren wurden in Kopenhagen verschiedene Versuche unternommen, um das für Wurzeln verfügbare Bodenvolumen zu vergröBern. Die gegenwärtige Studie untersuchte Wachstum und Vitalität von gepflanzten Bäumen in a. strukturiertem Lasttragenden Boden, b. sandigem, Lasttragenden Boden, c. so genannten SuperPflanzlöchern und Bäumen in gewöhnlichen Pflanzlöchern. Die Bäume waren entweder Straßenbäume oder sie standen in gepflasterten Quadraten. Die Ergebnisse zeigten, dass die Vitalität von kürzlich etablierten Straßenbäumen in Kopenhagen generell einen akzeptablen Level erreicht. Mehr noch, das Baumwachstum in beiden der lasttragenden Materialien mit Wurzelraum schien vergleichbar mit dem Wachstum von Bäumen in konventionellen Pflanzlöchern und diese Methoden scheinen daher vergleichbar mit dem Baumwachstum in konventionellen Pflanzlöchern zu sein und können somit für Standorte geeignet zu sein, wo sich konventionelle Pflanzgruben nicht herstellen lassen. Dennoch ist das Wachstum in Super-Pflanzgruben besser als in allen andern in Bezug auf Wachstumsrate und Vitalität. Diese Methode ist daher empfehlenswert, wo immer Platz genug ist für große Pflanzlöcher mit offenen Oberflächen. Das Wachstum von Bäumen in konventionellen Pflanzgruben variierte deutlich und reflektierte die breite Reichweite von unterschiedlichen Bedingungen, die der Begriff, "konventionelles Pflanzen" einschließt.

Resumen. El limitado espacio de enraizamiento es considerado un grave problema para el crecimiento de los árboles de las calles. Durante los últimos 15 años se han intentado diferentes acercamientos para lograr un volumen de suelo accesible a las raíces en la ciudad de Copenhagen, Dinamarca. La presente encuesta investiga el crecimiento y vitalidad de árboles plantados en: a) suelo estructurado, b) suelo estructurado arenoso, c) sitios convencionales. Los árboles fueron situados bien sea en la calle o en plazas pavimentadas. Los resultados proveen evidencia de que la vitalidad de los árboles urbanos recién establecidos en Copenhagen generalmente está en un nivel aceptable. Además, el crecimiento de los árboles en ambos materiales, para permitir el crecimiento de las raíces, se encontró comparable al crecimiento en sitios convencionales, y estos métodos son por tanto considerados aplicables a sitios donde los pozos convencionales no pueden ser establecidos. Sin embargo, el crecimiento de los árboles en pozos de plantación fue superior a cualquiera de los otros métodos relacionados con las tasas de crecimiento y vitalidad. Este método es recomendado donde se requiera espacios para grandes sitios de plantación con espacios abiertos. El crecimiento de los árboles plantados en pozos convencionales varió considerablemente, reflejando el amplio rango de condiciones diferentes que cubre el término "plantación convencional". 